
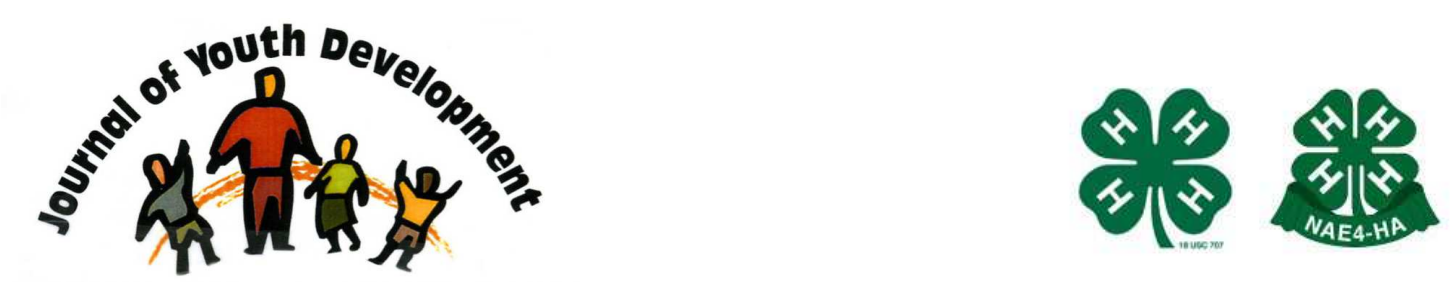

Bridging Research \& Practice

\title{
Hispanics and Health Care in the United States: Access, Information and Knowledge
}

\author{
Patricia Dawson \\ Oregon State University \\ Pendleton, OR \\ patricia.dawson@oregonstate.edu
}




\title{
JOURNAL OF YOUTH DEVELOPMENT \\ bridging research and practice

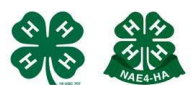

\section{Hispanics and Health Care in the United States: Access, Information and Knowledge}

\author{
Patricia Dawson \\ Oregon State University
}

\begin{abstract}
The Hispanic population is the largest growing minority group in the United States. A helpful resource to assist in designing programs and interventions aimed at Hispanic communities was recently completed by the Pew Hispanic Center and Robert Wood Johnson Foundation. Over 4,000 Hispanic adults were included in the study which highlights how the diverse characteristics of the Hispanic population affect their health care needs and their comprehension of health care resources.
\end{abstract}

\section{Introduction}

The Hispanic population in the United States has more than doubled in the past 15 years (Passel, J., \& Cohn, D., 2008). Studies have found that more than one-fourth of Hispanic adults in the United States lack a usual health care provider with eight in ten Hispanics indicating they receive health information from sources such as radio or television (Pew Research Center, 2008).

An excellent resource which addresses Hispanic Health Care is the research report titled "Hispanics and Health Care in the United States: Access, Information and Knowledge." This joint Pew Hispanic Center and Robert Wood Johnson Foundation Research Report is written by Livingston, Minushkin, and Cohn, and published in 2008.

The eighty page document includes an executive summary, four chapters and detailed tables which highlight results from a telephone survey of over 4,000 Hispanic adults. Major themes include:

1. Introduction, Hispanics and Chronic Disease in the U.S.

2. Utilization of a usual health care provider and satisfaction with health care. 
3. Sources of information on health and health care.

4. How much do Hispanics know about diabetes?

Easy to comprehend charts, figures and tables aid readers in understanding the researchers' findings. Methodology for the study and 14 charts and tables are included in the Appendix. Contents address critical findings such as a Diabetes Knowledge Index, and an analysis of the Impact of Media on Behavior.

This resource may be downloaded at www.pewhispanic.org/files/reports/91.pdf. The study provides useful data for designing programs and interventions aimed at the Hispanic communities.

Readers are encouraged to visit the Pew Hispanic Center or Robert Wood Johnson Foundation for additional resources.

\section{References}

Livingston, G., Minushkin, S., \& Cohn, D. (2008). Hispanics and Health Care in the Unites States...Access, Information and Knowledge. A joint Pew Hispanic Center and Robert Wood Johnson Foundation Research Report. Download at www.pewhispanic.org/files/reports/91.pdf.

Passel, J., Cohn, D. (2008). U.S. Population Projections: 2005-2050. Pew Research Center.

(C) Copyright of Journal of Youth Development Bridging Research and Practice. Content may not be copied or emailed to multiple sites or posted to a listserv without copyright holder's express written permission. However, users may print, download or email articles for individual use. 